Coventry University and

The University of Wisconsin Milwaukee Centre for By-products Utilization, Second International Conference on Sustainable Construction Materials and Technologies June 28 - June 30, 2010, Università Politecnica delle Marche, Ancona, Italy. Main Proceedings ed. J Zachar, P Claisse, T R Naik, E Ganjian. ISBN 978-1-4507-1490-7 http://www.claisse.info/Proceedings.htm

\title{
Paper Mill Sludge Ash as Supplementary Cementitious Material
}

\section{Valeria Corinaldesi, Gabriele Fava, and Maria Letizia Ruello}

Department of Materials and Environment Engineering and Physic (FIMET), Università Politecnica delle Marche, Via Brecce Bianche, 60131, Ancona, Italy, E-mail: <v.corinaldesi@univpm.it>,<g.fava@univpm.it>,<m.l.ruello@univpm.it>.

\begin{abstract}
Paper mill sludge is often incinerated for heat recovering and also for an important volume reduction. In Italy about $6 \times 10^{5}$ tons of paper sludge is yearly produced giving $60 \mathrm{~kg}$ of paper ash per ton. In this project, the ash coming from burning of paper mill sludge from primary mechanical separation process, fired as single fuel, was studied in order to evaluate its use as supplementary cementitious material in concrete manufacturing. On the basis of the data collected it can be concluded that the paper mill sludge ash, if replaced by 5 to $10 \%$ of Portland cement, show a positive effect on the mechanical performance of the concrete. On the other hand, due to its high fineness and consequently high water absorption, it requires a higher dosage of water, so that the use of paper ash should not be higher than $10 \%$ by weight of cement.
\end{abstract}

\section{INTRODUCTION}

Unsustainable trends in waste generation are causes for concern because the generation of waste can be a symptom of environmentally inefficient use of resources [OECD]. Transforming waste may mitigate but not solve present and future environmental problems; however, organic sludge may play a desirable role as an auxiliary fuel. Paper sludge is generally understood as a waste stream originating from water-treatment rejects that are separated from the mill effluent during the treatment process of (recovered) virgin or recycled paper. Objectives of both EU and Italian national waste policy are to minimize production of waste and to promote re-use, recycling, and recovery so as to reduce its negative environmental impact. Europe produces about 1.3 billion tons per year of such sludge, which comes principally from the paper manufacturing and paper-recycling industries. This huge amount produces a severe impact on the environment and drives European governments to encourage and promoting any processes that will enable its reduction and/or possible valorisation.

In 2004 , the production of paper mill sludge in Italy was around $6 \cdot 10^{5}$ tons [Asquini et al. 2008]. Approximately $1 / 3$ of the waste paper volume processed in recycling plants becomes sludge and rejects [Göttsching et al. 1996]. The disposal of residual paper sludge is a problem confronting the paper industry, which is compounded by the increasing demand towards recycling of used papers. Almost paradoxically, increased recycling has provoked a significant increase of the amount of sludge being generated. Additionally, the interest for energy recovery from paper sludge is growing as landfilling is becoming increasingly expensive and less viable in many of the countries. For these reasons, the use of paper sludge for energy production has encountered increased attraction as being a cost-effective, and an 
environmentally acceptable disposal method [Anthony et al, 1993]. Paper mill sludge is composed of mineral fillers, inorganic salts, small cellulose fibers, water, and organic compounds. About $60 \mathrm{~kg}$ of ash is produced per ton of paper mill sludge. The composition of mineral fillers depends on the type of paper produced. Paper mill sludge is often incinerated in order to reduce the volume of the waste disposal and to recover heat. This process is achieved first by de-watering (i.e., by mechanical means and/or evaporation) at low temperature $\left(<200^{\circ} \mathrm{C}\right)$, followed by incineration at high temperature $\left(>800^{\circ} \mathrm{C}\right)$. During incineration, organic compounds are burned at temperatures of around 350 to $500{ }^{\circ} \mathrm{C}$, whereas mineral fillers and inorganic salts are transformed into the corresponding oxides at higher temperatures $\left(>800^{\circ} \mathrm{C}\right) . \mathrm{CaO}, \mathrm{Al}_{2} \mathrm{O}_{3}, \mathrm{MgO}$, and $\mathrm{SiO}_{2}$ are the most abundant oxides in incinerated paper mill sludge [Liaw et al. 1998]. The resulting paper mill-sludge ash is classified as waste, and at present it is mainly sent to landfill at high costs. Recycling it would have beneficial effects for paper producers and the environment as well. A possible reuse of the paper mill sludge is its blending with natural raw materials extracted from the ores in the production of bricks or cements [Marcis et al. 2005, Ernstbrunner 2007, Liaw et al. 1998], since the main constituent elements of paper mill sludge are $\mathrm{Al}, \mathrm{Mg}, \mathrm{Si}$ and $\mathrm{Ca}$, whose oxides are largely used in the such ceramics industries. Therefore, burning paper sludge represents two sources of cost saving for a paper mill: reduced disposal costs and reduced fuel consumption for steam generation/energy production.

The option to utilize paper sludge as a co-firing (bio-waste) fuel for energy production has been considered in many European countries as well as USA and Japan. The organic fraction in paper sludge is renewable; and, therefore, it is not considered as contribution to the net $\mathrm{CO}_{2}$ emissions.

The present study was conducted in the framework of a research project aiming at improving the utilization potential of paper sludge ash (PA) and at evaluating the possibility of its use as a cement replacement in concrete manufacturing.

\section{EXPERIMENTAL INVESTIGATION}

\section{Materials}

A commercial Portland-limestone (20\% maximum limestone content) blended cement, Type CEM II/A-L 42.5 R according to EN-197/1, was used. The Blaine fineness of the cement was $410 \mathrm{~m}^{2} / \mathrm{kg}$, and its specific gravity was $3.05 \mathrm{~kg} / \mathrm{dm}^{3}$.

The paper ash used came from burning of paper mill sludge, and testing shows the following main properties: Blaine fineness $635 \mathrm{~m}^{2} / \mathrm{kg}$, and specific gravity $1.72 \mathrm{~kg} / \mathrm{dm}^{3}$. In order to characterize the paper-ash, thermal analysis and X-ray diffraction were carried out. Thermal analysis showed that the ash material contained about $6 \%$ of calcite, $\mathrm{CaCO}_{3}$. As it can be observed in Figure 1, a sharp weight loss, corresponding to the flex of the differential thermal analysis (DTA) curve occurs from about $600^{\circ} \mathrm{C}$ to $800^{\circ} \mathrm{C}$ while strong heat absorption is detected. This is due to the decomposition reaction of calcite, which is endothermic. X-ray diffraction analysis (Fig. 2) show also the presence of calcium oxide $(\mathrm{CaO})$, gehlenite $\left(\mathrm{Ca}_{2} \mathrm{Al}_{2} \mathrm{SiO}_{7}\right)$, and mayenite $\left(\mathrm{Ca}_{12} \mathrm{Al}_{14} \mathrm{O}_{33}\right)$. In addition, other components such as talc $\left(3 \mathrm{MgO}^{*} 4 \mathrm{SiO}_{2} * \mathrm{H}_{2} \mathrm{O}\right)$, barium sulphate $\left(\mathrm{BaSO}_{4}\right)$, and zinc oxide $(\mathrm{ZnO})$ may also be present in small and variable percentages. Toxic trace metal concentration mostly observed from recycled paper were found at very low level, lower than the analysis sensitivity of $1 \mathrm{ppm}$. Paper ash was observed at increasing magnifications by means of scanning electron microscope (SEM, Fig. 3). 


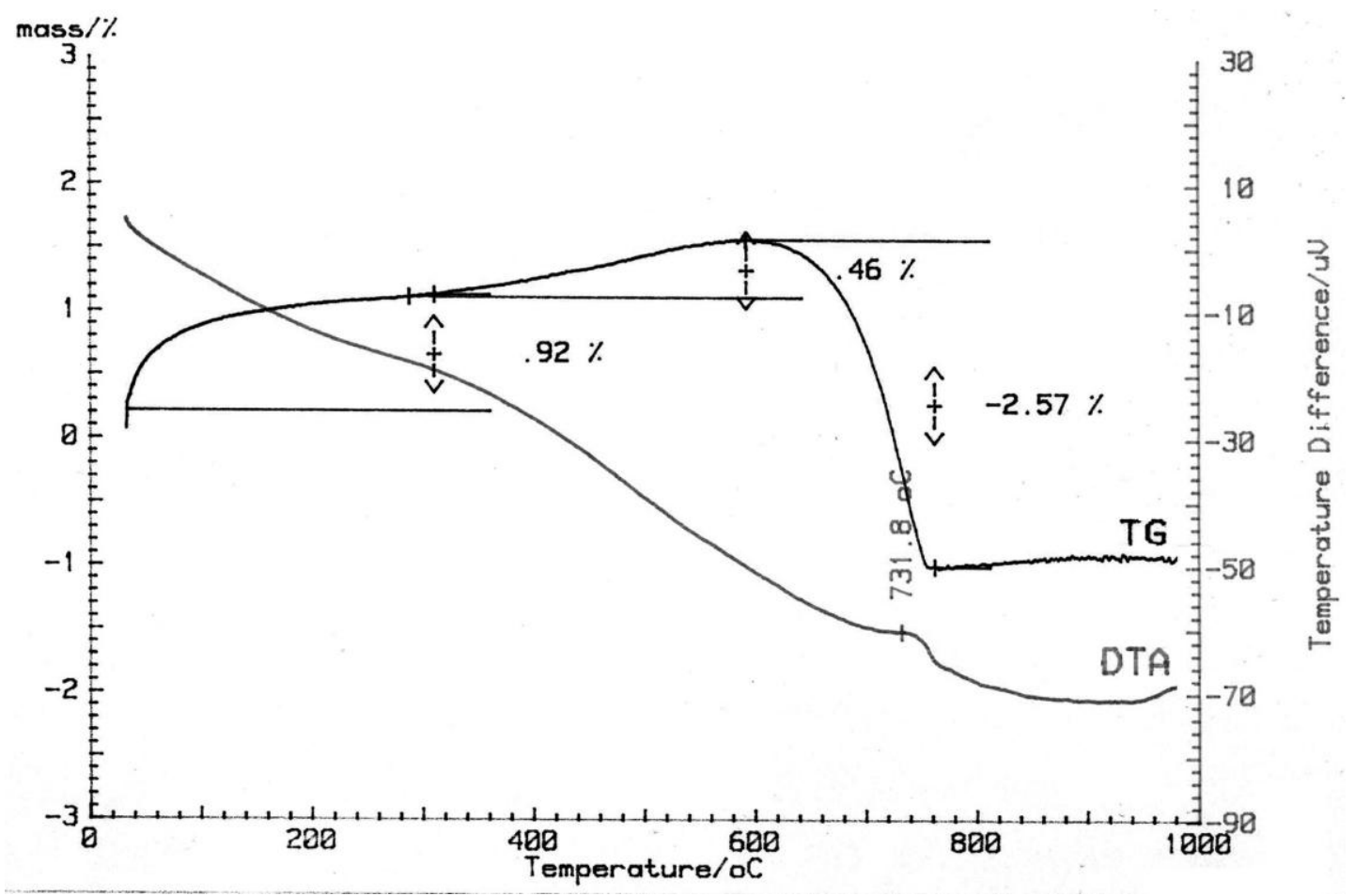

Figure 1. Results of the thermo-gravimetric (TG) and differential thermal analysis (DTA) of the paper-ash.

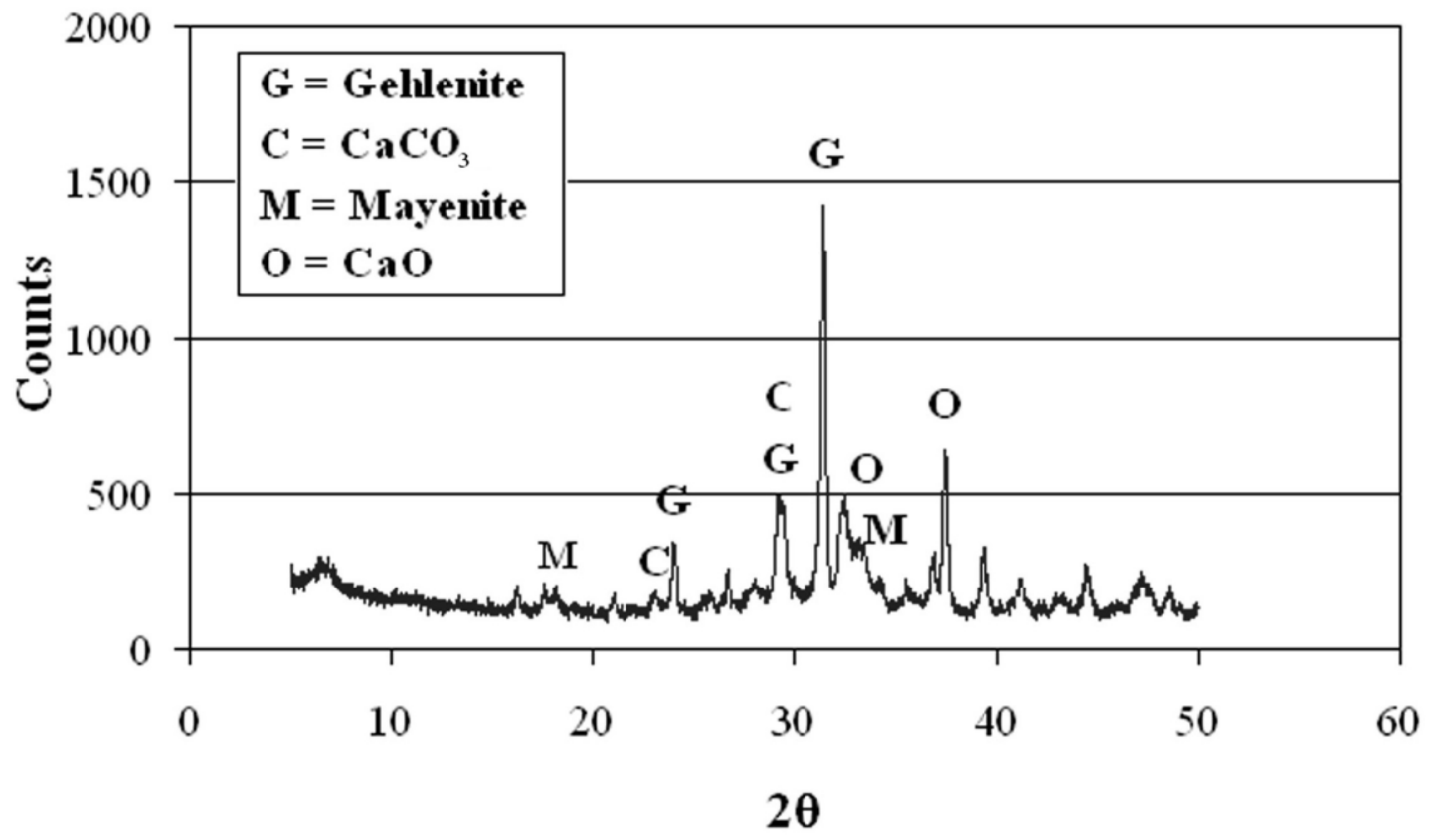


Figure 2. X-ray diffraction of the paper-ash.
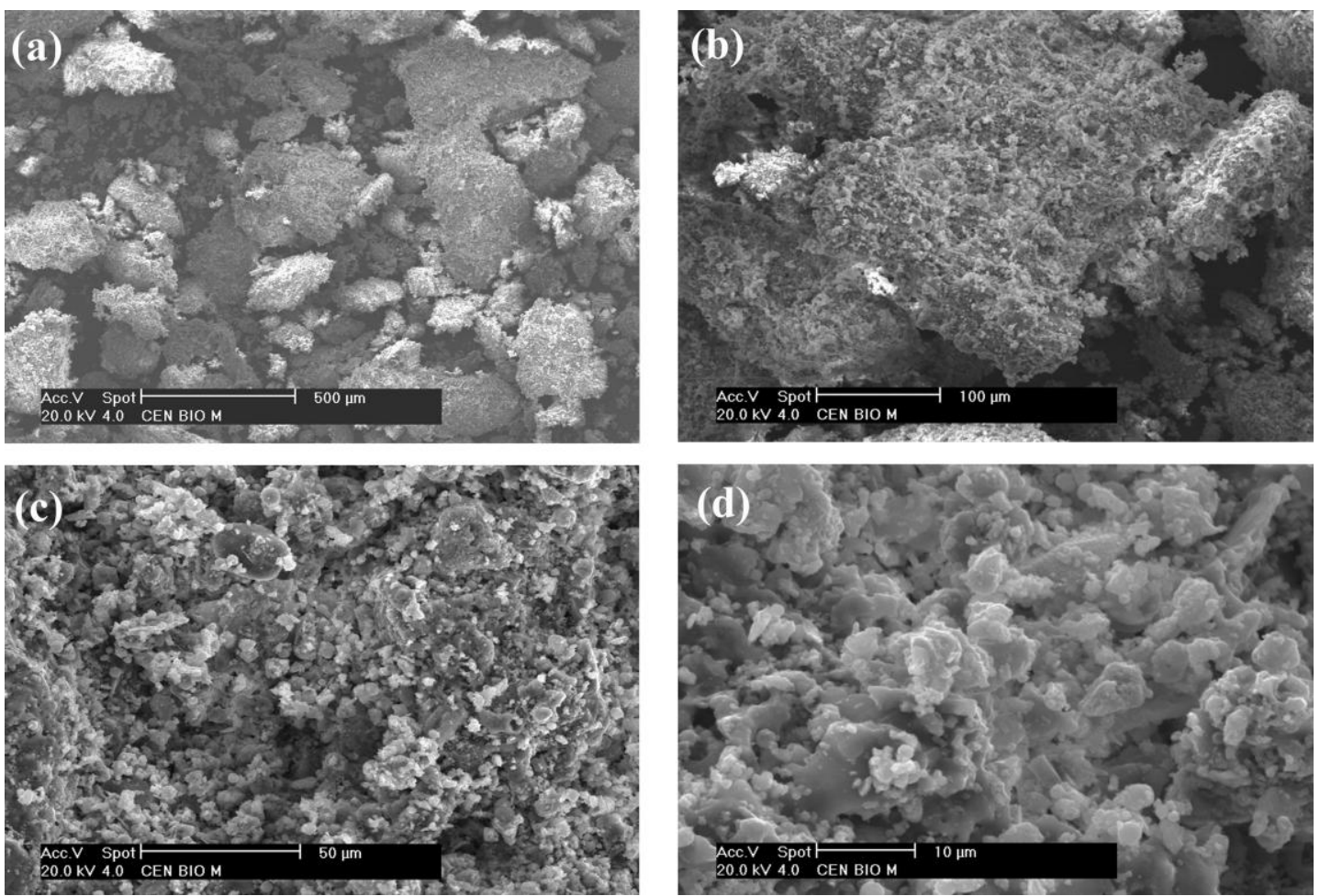

Figure 3. SEM observations of the paper-ash at different magnifications: $500 \mu \mathrm{m}$ (a), $100 \mu \mathrm{m}(\mathrm{b}), 50 \mu \mathrm{m}(\mathrm{c})$ and $10 \mu \mathrm{m}(\mathrm{d})$.

Natural sand (range of particle size: $0-5 \mathrm{~mm}$ ) and natural gravel (range of particle size: 2-12 $\mathrm{mm})$ were used in each concrete mixture. Their main physical properties, determined according to EN 1097-6 and EN 933-1, are reported in Table 1.

\section{Table 1. Physical properties of sand and PA fraction.}

\begin{tabular}{|c|c|c|c|}
\hline Fraction & $\begin{array}{c}\text { Water absorption } \\
(\%)\end{array}$ & $\begin{array}{c}\text { Specific gravity in SSD } \\
\text { condition }\left(\mathrm{kg} / \mathrm{m}^{3}\right)\end{array}$ & $\begin{array}{c}\text { Passing } 75 \mu \mathrm{m} \\
\text { sieve }(\%)\end{array}$ \\
\hline Natural sand & 4.1 & 2530 & 0.7 \\
\hline Paper Ash & 25 & 1720 & 80 \\
\hline
\end{tabular}

${ }^{(*)} \mathrm{SSD}=$ saturated surface-dried

A typical water-reducing admixture based on polycarboxylate polymers (30\% aqueous solution) was used for preparing all concrete mixtures.

Specimens. Mortar mixtures were prepared with three different water to binders ratios: 0.4 , 0.5, and 0.6. Paper ash was added to the mortars mixtures at different percentages: 0, 5, 10, 15 , and $20 \%$ by weight of the cement. Mortars mixture proportions are reported in Table 2. 
The dosage of superplasticizer was always equal to $1.0 \%$ by weight of the cement in order to reduce the water dosage by about $30 \%$. The concrete workability was similar for all the concrete mixtures and equal to 180-190 mm slump/spread (measured according to EN 123502).

Table 2. Mixture proportions of mortars prepared with different percentages of paper ash (PA).

\begin{tabular}{|c|l|l|c|c|}
\hline \multirow{2}{*}{ Mixture } & \multirow{2}{*}{ Water/Binder } & \multicolumn{3}{|c|}{ Ingredient dosage (g) } \\
\cline { 3 - 5 } & & Water & Cement & Paper Ash \\
\hline $0.4-0 \% \mathrm{PA}$ & 0,400 & 180 & 450,0 & 0,0 \\
\hline $0.4-5 \% \mathrm{PA}$ & 0,405 & 180 & 427,5 & 22,5 \\
\hline $0.4-10 \% \mathrm{PA}$ & 0,411 & 180 & 405 & 45,0 \\
\hline $0.4-15 \% \mathrm{PA}$ & 0,418 & 180 & 382,5 & 67,5 \\
\hline $0.4-20 \% \mathrm{PA}$ & 0,425 & 180 & 360,0 & 90,0 \\
\hline $0.5-0 \% \mathrm{PA}$ & 0,500 & 225 & 450,0 & 0,0 \\
\hline $0.5-5 \% \mathrm{PA}$ & 0,511 & 225 & 427,5 & 22,5 \\
\hline $0.5-10 \% \mathrm{PA}$ & 0,522 & 225 & 405,0 & 45,0 \\
\hline $0.5-15 \% \mathrm{PA}$ & 0,535 & 225 & 382,5 & 67,5 \\
\hline $0.5-20 \% \mathrm{PA}$ & 0,550 & 225 & 360,0 & 90,0 \\
\hline $0.6-0 \% \mathrm{PA}$ & 0,600 & 270 & 450,0 & 0,0 \\
\hline $0.6-5 \% \mathrm{PA}$ & 0,616 & 270 & 427,5 & 22,5 \\
\hline $0.6-10 \% \mathrm{PA}$ & 0,633 & 270 & 405,0 & 45,0 \\
\hline $0.6-15 \% \mathrm{PA}$ & 0,653 & 270 & 382,5 & 67,5 \\
\hline $0.6-20 \% \mathrm{PA}$ & 0,675 & 270 & 360,0 & 90,0 \\
\hline
\end{tabular}

Fifteen concrete prismatic specimens $(40$ x 40 x $160 \mathrm{~mm}$ ) from each mixture were prepared for mechanical characterization of the mortar. All the specimens with the water to binder ratio of nominal values of 0.4 and 0.6 were wet cured at the temperature of about $20^{\circ} \mathrm{C}$, while the others with a water to binder ratio of 0.5 were cured at a summer temperature of about $27^{\circ} \mathrm{C}$. Curing temperature was included as an additional numerical input, beside specimen age, water to binder ratio and mortar composition to obtain a more qualitative understanding of the effects of paper ash on cement. 


\section{RESULTS AND DISCUSSIONS}

The compressive strengths of mortars were measured after 1, 7, 28, and 60 days after casting. Data well fitted the Carino-Knudsen relationship, giving the opportunity to evaluate the maximum compressive strength $\left(f_{\max }\right)$ and the form parameters through the expression:

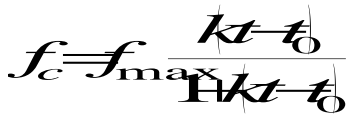

where $f_{c}$ is the compressive strength predicted at a given time $t ; t_{0}$ is the time needed before the strength gain begins ( $t_{0}=0$ was considered), $f_{\max }$ is the final strength when $t$ tends to infinity; and $k$ expressed in days ${ }^{-1}$ is a constant. The results obtained and synthesized are shown in Tables 3 and 4, and, also, in Figure 4.

Table 3. Compressive strength values (MPa) measured on cement mortars prepared with different percentages of paper ash (PA).

\begin{tabular}{ccccc}
\hline \multirow{2}{*}{ Mixture } & \multicolumn{5}{c}{ Curing time (days) } \\
& 1 & 7 & 28 & 60 \\
\hline $0.4-0 \% \mathrm{PA}$ & 13.4 & 37.8 & 44.1 & 51.2 \\
\hline $0.4-5 \% \mathrm{PA}$ & 7.3 & 36.0 & 44.9 & 51.2 \\
\hline $0.4-10 \% \mathrm{PA}$ & 2.6 & 30.4 & 37.4 & 50.0 \\
\hline $0.4-15 \% \mathrm{PA}$ & 9.4 & 27.0 & 42.3 & 46.5 \\
\hline $0.4-20 \% \mathrm{PA}$ & 11.8 & 35.7 & 42.4 & 45.0 \\
\hline $0.5-0 \% \mathrm{PA}$ & 19.5 & 33.2 & 37.1 & 39.4 \\
\hline $0.5-5 \% \mathrm{PA}$ & 15.2 & 33.3 & 36.5 & 39.9 \\
\hline $0.5-10 \% \mathrm{PA}$ & 14.5 & 30.5 & 32.5 & 35.7 \\
\hline $0.5-15 \% \mathrm{PA}$ & 15.5 & 27.8 & 31.2 & 32.6 \\
\hline $0.5-20 \% \mathrm{PA}$ & 12.2 & 23.0 & 29.1 & 29.9 \\
\hline $0.6-0 \% \mathrm{PA}$ & 7.7 & 19.8 & 26.1 & 30.7 \\
\hline $0.6-5 \% \mathrm{PA}$ & 4.2 & 20.2 & 24.8 & 30.5 \\
\hline $0.6-10 \% \mathrm{PA}$ & 3.2 & 18.1 & 24.9 & 28.3 \\
\hline $0.6-15 \% \mathrm{PA}$ & 4.5 & 14.9 & 21.1 & 26.6 \\
\hline $0.6-20 \% \mathrm{PA}$ & 5.1 & 15.3 & 20.6 & 22.7 \\
\hline
\end{tabular}

Table 4. Carino-Knudsen parameters for mortars prepared with different percentages of paper ash (PA).

\begin{tabular}{ccccccc}
\hline$\%$ PA & $\begin{array}{c}f_{\max } \\
\mathrm{w} / \mathrm{b}=0,4\end{array}$ & $\begin{array}{c}k \\
\mathrm{w} / \mathrm{b}=0,4\end{array}$ & $\begin{array}{c}f_{\max } \\
\mathrm{w} / \mathrm{b}=0,5\end{array}$ & $\begin{array}{c}k \\
\mathrm{w} / \mathrm{b}=0,5\end{array}$ & $\begin{array}{c}f_{\max } \\
\mathrm{w} / \mathrm{b}=0,6\end{array}$ & $\begin{array}{c}k \\
\mathrm{w} / \mathrm{b}=0,6\end{array}$ \\
\hline 0 & 51.49 & 0.36 & 38.89 & 0.95 & 29.65 & 0.30 \\
\hline 5 & 53.92 & 0.24 & 40.08 & 0.63 & 31.45 & 0.22 \\
\hline 10 & 51.81 & 0.22 & 36.11 & 0.69 & 30.50 & 0.19 \\
\hline 15 & 50.98 & 0.17 & 32.74 & 0.88 & 28.19 & 0.15 \\
\hline 20 & 47.01 & 0.39 & 30.29 & 0.59 & 23.84 & 0.26 \\
\hline
\end{tabular}


The data point to the good performances obtained with PA replacing 5\% of cement with all the water to binder ratio. For a proper evaluation of the PA effect, it was also necessary to correct the water to binder ratio for all mortars containing paper ash taking into account the water absorbivity of PA. The nominal water to binder ratio when corrected varied in the range of 0.40 to 0.67 . Cement replacement from 10 up to $20 \%$ with paper ash seems to reduce the mechanical performance of mortars whatever the water to binder ratio. However, the maximum compressive strength reduction $\left(f_{\max }\right)$ ranged from $12 \%$ to $26 \%$ with an increase of PA from 0 to $20 \%$. With higher ash contents, the strength development seems to slow down, particularly for the higher water to cement ratio $(0.60)$.
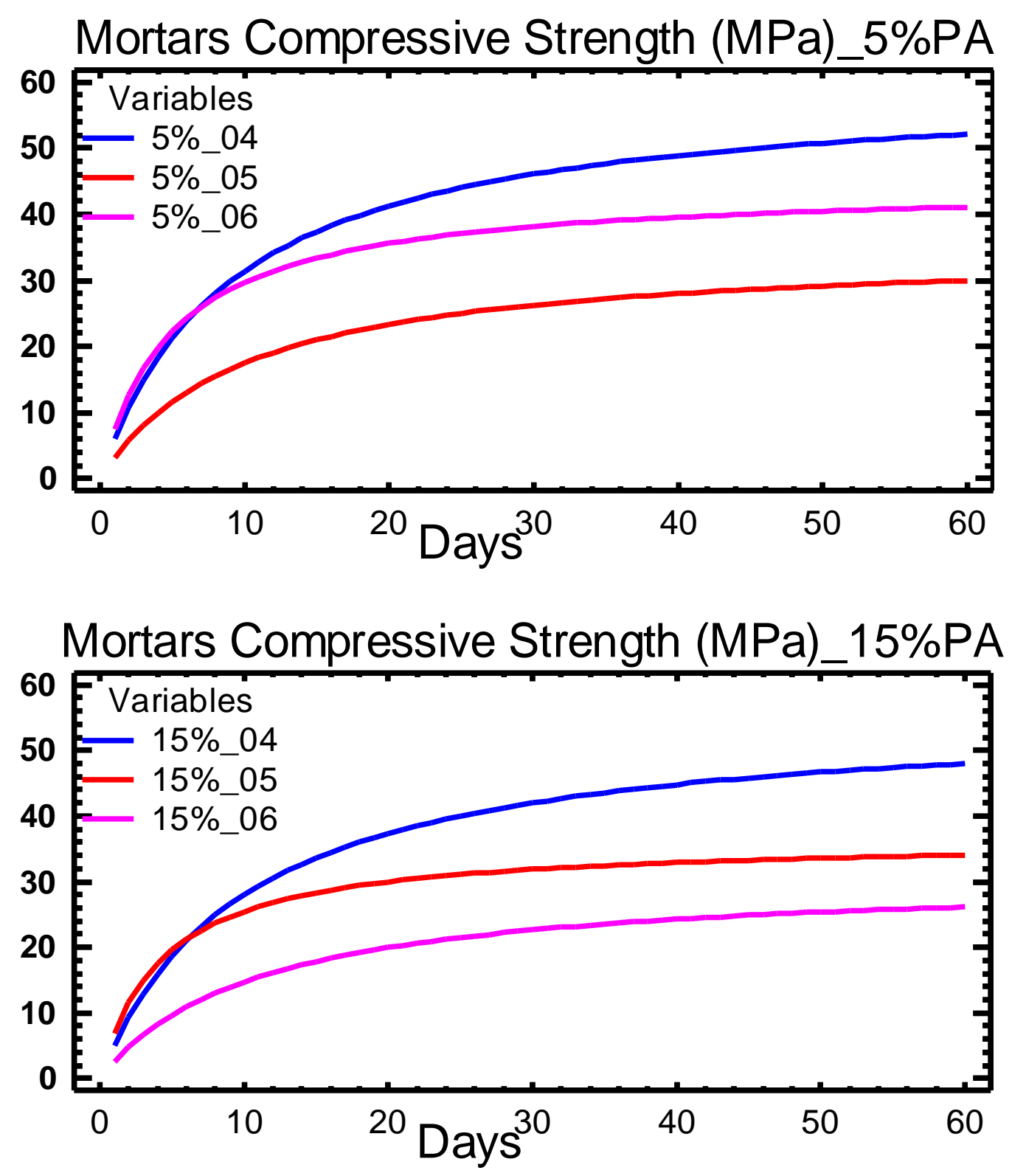

Figure 4. Strength developments of mortars with nominal water to cement ratio of $0.4 ; 0.5$, and 0.6 with $5 \%$ and $15 \%$ PA substituted for Portland cement. 
Further insight, in order to clarify the reasons of the behavior detected for the mortars prepared with 5\% PA replacing cement, can be obtained following the Abrams equation as modified by Popovics for taking into account a possible chemical or physical effect for PA.

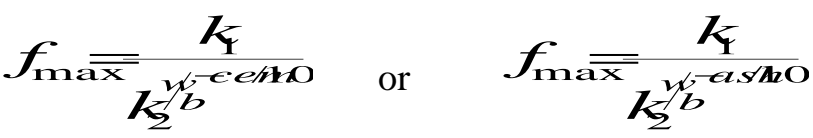

The data (Figure 5) fitted quite well giving the following relationship

$f_{\max }=1 /\left(-9.19 \cdot 10^{-3} \cdot+6.60 \cdot 10^{2} \cdot w / b\right) \quad$ Pearson's correlation coefficient $R^{2}=0.92$

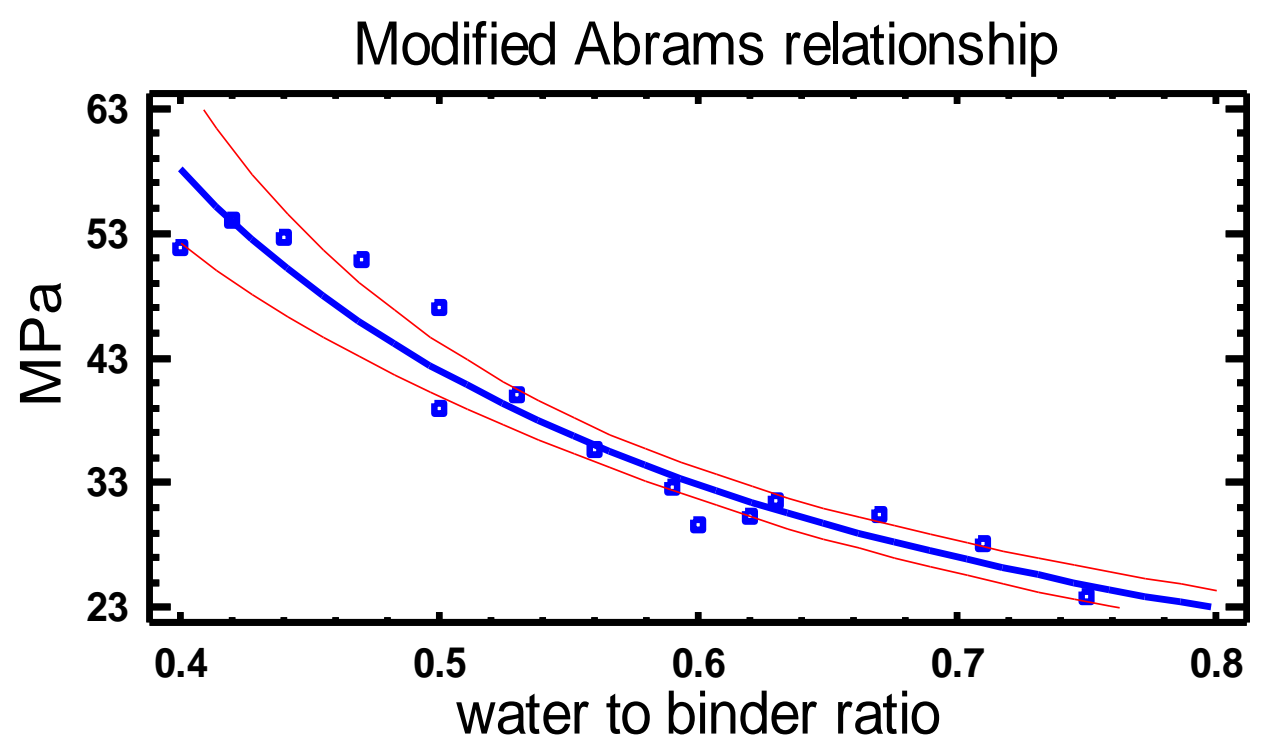

Figure 5. Modified Abrams relationship

A better description can be obtained taking into account a second order interaction between the cement and PA as can be shown in the following equation and Figure 6.

$f_{\max }=96.39-101.9 \cdot w / b+1.54 \cdot 10^{-4} \cdot c e m \cdot a s h-8.43 \cdot k \quad$ Pearson's correlation coefficient $R^{2}=0.98$ 


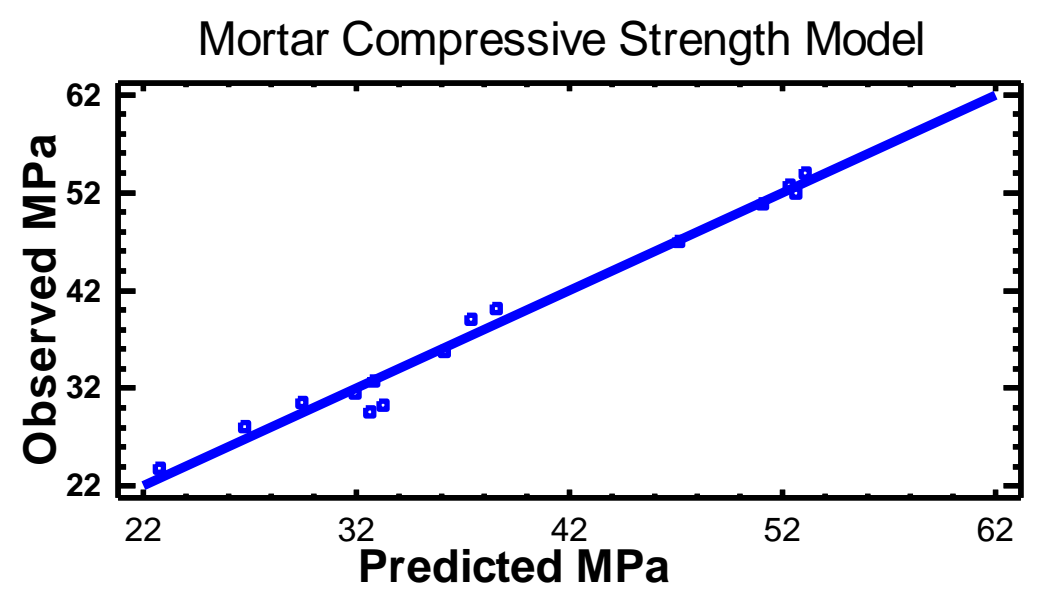

\section{Figure 6. Mortar compressive strength model.}

\section{CONCLUSIONS}

Based on the experimental results of this study the following observations can be drawn:

- The mortars containing 5\% PA exhibited a compressive strength higher or as high as that of mortar made from OC at 28 days.

- The results presented encourage the researchers to undertake further study on the use of PA in concrete, which could lead to a reduction in the cost of concrete as well as a method for disposal of PA.

On the basis of the data collected within this experimental project, it can be concluded that the paper-ash, particularly if it replaces less than $10 \%$ of cement, show a positive effect on time development of concrete mechanical performance. Probably, paper ash can give an active contribution to cement paste hardening (positive value of the cement activity index). On the other hand, due to its high fineness, and consequently high water absorption, the dosage of PA should not be too high (the upper limit appears to be $10 \%$ by weight of cement).

\section{REFERENCES}

Abrams, D. A. (1918). "Design of concrete mixtures. Bulletin 1." Structural Materials Research Laboratoty, Lewis Institute, Chicago.

Anthony, E., Preto, F., Herb, B. E., Lewnard, J. J. (1993). "The Technical, Environmental, and Economic Feasibility of Recovering Energy from Paper Mill Residual Fibers." Fluidized Bed Combustion, Vol. 1, 239-247, ASME.

Asquini, L., Furlani, E., Bruckner, S., Maschio, S. (2008). "Production and characterization of sintered ceramics from paper mill sludge and glass cullet". Chemosphere 71, 83-89.

Carino, N. J. (1984). "The maturity method: theory and application." Cement, Concrete and Aggregates. ASTM Vol.6 N.2, 61-67

D.M.A. 5 febbraio 1998. Individuazione dei rifiuti non pericolosi sottoposti alle procedure semplificate di recupero ai sensi degli articoli 31 e 33 del Decreto Legislativo 5 febbraio $1997 \mathrm{n}^{\circ} 22$ (Identification of non-dangerous wastes undergoing recovery simplified procedure according to articles 31 and 33 in Legislative Decree 5 February

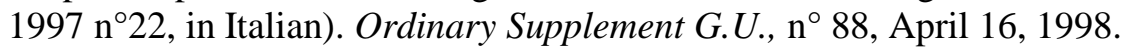


EN 197-1. Cement - Part 1: Composition, specifications and conformity criteria for common cements, 2000.

EN 450-1. Fly ash for concrete, 2005.

EN 933-1. Tests for geometrical properties of aggregates - Determination of particle size distribution - Sieving method, 1997.

EN 1097-6. Tests for mechanical and physical properties of aggregates - Determination of particle density and water absorption, 2000.

EN 12350-2. Testing fresh concrete - Slump test, 1999.

Ernstbrunner, L. (1997). "Rejects from paper manufacture utilized in the cement works." Papier 51 (6), 284-286.

Göttsching, L., Hamm, U, Platzer, E., Putz, H. J. (1996). “Analysis of Waste Paper Recycling and Disposal Options in Germany.” IIED Report.

Knudsen, T., (1980). "On Particle size distribution in cement hydration." Proceeding of the $7^{\text {th }}$ Int. Congr. On the Chemistry in Cement, Ed. Septima, Paris. V.2

OECD. Environmental outlook for the chemical industry. Paris, France OECD 2001.

Liaw, C. T., Chang, H. L., Hsu, W .C., Huang, C. R. (1998). "A novel method to reuse paper sludge and cogeneration ashes from paper mill." J. Hazard. Mater. 58, 93-103.

Marcis, C., Minichelli, D., Bruckner, S., Bachiorrini, A., Maschio, S. (2005). "Production of monolithic ceramics from incinerated municipal sewage sludge, paper mill sludge and steelworks slag." Ind. Ceram. 25 (2), 89-95.

Popovics, S. (1998) Strength and Related Properties of Concrete, Wiley New York

Popovics, S., Ujhelyi, J. (2008). "Contribution to Concrete strength versus Water-Cement Ratio Relationship.” J.Mater.Civ. Eng. 20(7), 459-463

Tay, J. H. (1990). "Ash from oil palm waste as concrete material." ASCE J. Mater. Civ. Eng. 2(2), 94-105 